\title{
A Comparison of Executive Functions in Normal Aging, Mild Cognitive Impairmant, and Early Stage Alzheimer Type Dementia in Turkish Sample
}

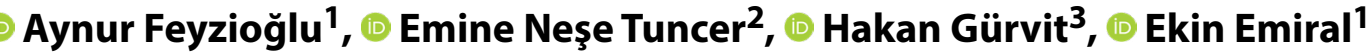 \\ ${ }^{1}$ Department of Clinical Psychology, University of Health Sciences, Turkey \\ ${ }^{2}$ Department of Neurology, Marmara University, Istanbul, Turkey \\ ${ }^{3}$ Department of Neurology, Istanbul University, Istanbul, Turkey
}

\begin{abstract}
Introduction: In this study, neuropsychological profiles of Mild Cognitive Impairment (MCl) and early-stage Alzheimer's Disease (AD) were explored with a comprehensive neuropsychological battery that evaluates attention, memory, executive functions, language, visual-spatial, and behavioral skills.

Methods: In this study, 60 people with minimum primary school degree were included. Twenty people of those with earlystage AD (12 women, 8 men), while 20 people were with $\mathrm{MCl}$ (10 women, 10 men). These groups were matched for age, sex and education with 20 normal elderly subjects ( 9 female, 11 male).

Results: Our findings showed that the general cognitive profile of $\mathrm{MCl}$ is manifested as episodic memory and a semantic memory disorder. In contrast, in early-stage AD patients, language, visual-spatial skills, executive function, abstraction and interference resistance skills were found to be impaired and episodic and semantic memory problems were observed.

Discussion and Conclusion: The results of the present study suggesting a distinguished profile of $\mathrm{MCl}$ can be a promising factor in distinguishing the fine boundary between $\mathrm{MCl}$ and early-stage AD with an opportunity for early diagnosis and treatment of AD in the Turkish sample.

Keywords: Dementia; early-stagestage Alzheimer's disease; executive functions; mild cognitive impairment; normal aging.
\end{abstract}

$T^{n+m a t a n}$ he intermediate state between the normal aging process and dementia that does not meet the diagnosis of dementia clinically can be named as mild cognitive impairment $(\mathrm{MCl}) . \mathrm{MCl}$ is described with memory-related complaints or objective memory loss that is not in congruence with the age of the individual accompanied by completely healthy or not problematic other cognitive func- tions and activities of daily living are preserved. According to Petersen ${ }^{[1]}, \mathrm{MCl}$ diagnostic criteria should consist of five factors: (1) the memory problem described by the patient him/herself, (2) determination of a memory defect based on the patient's age (the episodic memory score should be less than at least 1.5 standard deviations from normal scores), (3) normal cognitive functions (other than mem- 
ory), (4) maintenance of daily activities, and (5) not enough symptoms for clinical diagnosis for dementia.

There is an ongoing debate about the extent to which the non-memory areas, especially executive functions, can be considered for the diagnosis of $\mathrm{MCl}^{[2]}$. Other cognitive functions, such as language, verbal fluency, or naming, are more severely impaired in patients with $\mathrm{MCl}$ than in patients with stable deficiencies. Disturbance in attention and executive functions is an early and sensitive pre-vision tool for the transformation of $\mathrm{MCl}$ to more severe problems in the future ${ }^{[3]}$. Most people with $\mathrm{MCl}$ correspond to 0.5 points, which is suspected dementia according to the Clinical Dementia Rating Scale $(C D R)^{[4-6]}$.

Alzheimer's Disease is a progressive degenerative brain disease characterized by an abnormal accumulation of senile plaques and neurofibrillary tangles with neocortical atrophy, extensive loss of neurons, and synapses. Evidence suggests that these neurodegenerative changes usually occur first and most commonly in the hippocampus and entorhinal cortex then into the association cortices of the frontal, temporal, and parietal lobes ${ }^{[7]}$. At the same time, $A D$ is a progressive brain disease that leads to extensive cognitive deficits, including memory, perception, attention, psychomotor and cognitive speed, visual-spatial functions, language, and intelligence ${ }^{[8]}$.

Impairment in executive functions may occur in the early-stages of the disease. The executive dysfunction in AD refers to the impaired abilities that are responsible for proper use of knowledge, conceptualization, problem solving, and cue-directed behavior. Patients with mild dementia with $A D$ are significantly unsuccessful in the tests requiring modification, self-monitoring, or sequencing compared with normal elderly subjects. For instance, in a study conducted by Bondi et al. ${ }^{[9]}$ showed that the number of categories completed in Wisconsin Card Sorting Test (WCST) was a significant criterion for differentiating early-staged AD subjects and normal elderly subjects. Moreover, Petersen et al. ${ }^{[1]}$ compared healthy controls with $\mathrm{MCl}$ patients, Pre-AD subjects (CDR 0.5), and early AD subjects (CDR 1) with various cognitive measures and as a result, all memory tests of $\mathrm{MCl}$ subjects (word list learning, paragraph learning and visual production) were reported to be significantly impaired compared to normal group and they were similar to those of AD group. However, the performance of the $\mathrm{MCl}$ group in other cognitive domains (such as naming, executive functions) was the same in healthy elderly controls.

In our study, early-staged cognitive Alzheimer's Disease, mild cognitive impairment, and normal subjects are aimed to be compared to determinate their cognitive profiles and for these three cases, determining the changes in executive functions formed our main research problems.

\section{Materials and Methods}

\section{Participants}

Sixty participants were included in this study. Twenty early-stage $A D$ patients ( 12 women, 8 men) and 20 patients with $\mathrm{MCl}$ (10 women, 10 men) were matched for age, gender and education who applied to the dementia outpatient clinic (Istanbul University, Istanbul Faculty of Medicine, Department of Neurology, Behavioral Neurology Policlinics and Marmara University, Faculty of Medicine; Department of Neurology Polyclinics) with the ethical permission of the institutes. Diagnosed groups were compared with 20 normal elderly (9 women, 11 men). The diagnosis of the patients who formed the patient groups was made according to the relevant criteria by experienced clinicians in evaluating dementia and memory disorders. The subjects were required to be at least primary school graduates. In the selection of normal subjects, inclusion criteria were not to have any neurological, psychiatric and systemic diseases.

A neuropsychological evaluation battery was used in this study with a series of neuropsychological tests. Namely, for attention Number Range (Wechsler Memory Scale sub-test) test; for executive functions Wisconsin Card Sorting Test and Stroop Test; for verbal fluency Animal Counting Test and K-A-S; for abstract thinking, Binary Similarities Test, Interpreting Proverbs Test; and finally, for behavioral status Geriatric Depression Scale and Frontal Behavior Inventory were used in this study.

Tests were applied to each subject individually by the researchers. The participants were given information about this study before the application without giving clues about tests. The subjects and the experimenter worked alone in an environment that was purified in the best possible way from physical stimuli such as overheat, disturbing light, and sound. The Frontal Behavior Inventory was completed by discussing the subjects with an informant who is a relative of the patient.

Tests and different parts of the tests were applied in the following sequence: (1) Number Range Test, (2) Stroop Test, (3) Wisconsin Card Sorting Test, (4) Category fluency (animal), (5) Phonemic fluency (K-A-S), (6) Binary Similarities, (7) Interpreting Proverbs, (8) Geriatric Depression Scale, (9) Application of Frontal Behavior Inventory to the patient. 


\section{Results}

Significance levels were calculated using a one-way analysis of variance (One-Way ANOVA) to look the difference between age and education variables in $A D, M C l$ and normal groups. The level of significance was accepted as .05. The data obtained by the neuropsychological tests used in our study showed a non-normal distribution in groups of $\mathrm{AD}, \mathrm{MCl}$ and normal subjects. Therefore, in the comparison analysis between the groups, non-parametric equivalents of the parametric tests (one-way ANOVA and t-test), namely, the Kruskal-Wallis Test and the Mann-Whitney-U Test were preferred.

For age and education, $\mathrm{AD}, \mathrm{MCl}$ and normal groups were compared with ANOVA Test, and no significant difference was found between the groups $(F(2,57)=0.56, p<0.05$; Table 1).

In all scales, $A D, M C l$ and normal groups were firstly compared with Kruskal-Wallis test and if the difference was found as statistically significant in those three groups, Man$\mathrm{n}$-Whitney $\mathrm{U}$ test was used to determine that which two groups had that difference (Table 2).

\section{Discussion}

In our study, neuropsychological evaluations were used to determine the cognitive profiles of early-stage $A D, M C l$ and normal cases and it was aimed to see the changes in the executive functioning of these three groups.

We used the Numerical Range Test to evaluate simple attention. The findings showed that early-stage AD group was different from only the normal group in the straight numerical range but different from both the $\mathrm{MCl}$ group and the normal group in the backward numerical range. There are different interpretations in the literature on this finding. Öktem ${ }^{[10]}$ states that attention distortion in patients with early-stage $A D$ occurs in the form of deterioration in com-

Table 1. Age and education descriptive statistics for $\mathrm{AH}, \mathrm{MCl}$, and normal group

\begin{tabular}{lccccc}
\hline Variable & N & Median & SD & Min. & Max. \\
\hline Age & & & & & \\
AD & 20 & 74.35 & 5.17 & 68 & 90 \\
MCl & 20 & 73.05 & 7.20 & 52 & 84 \\
$\quad$ Normal & 20 & 72.20 & 6.86 & 57 & 87 \\
Education & & & & & \\
AD & 20 & 9.90 & 3.54 & 5 & 15 \\
MCl & 20 & 12.20 & 3.97 & 5 & 20 \\
Normal & 20 & 11.15 & 4.12 & 5 & 19 \\
\hline
\end{tabular}

plex attention rather than simple attention with emphasizing that simple attention, measured by forward and reverse number-range tests, is maintained. Attention impairments, especially sustained in $A D$ and selective attention, could be used as an indicator for $A D^{[11]}$. Berardi et al. ${ }^{[12]}$ showed that $A D$ patients had lower performance on concentrating both automatic and effortful tasks. Besides AD patients, the possible AD patients showed impairments in a selective attention task. Weintraub ${ }^{[13]}$ notes that attention deficits may sometimes be seen in early-stage $A D$ or may occur even before memory impairment. In concordance with this, a simple attention deficit was detected in the AD group in our study. Also, the performance of the AD group in the reverse number range test was significantly lower than $\mathrm{MCl}$ and normal groups. Lezak ${ }^{[14]}$ argues these tests to be considered as two different test formats: forward number range as an attention test and backward number range as working memory test. We think that the problems in the backward number range achieved in our study are related to this explanation. Our findings are also consistent with the results of a study conducted in Turkey ${ }^{[15]}$ wherein the forward number range in the AD group is within normal limits compared to normative values, while the backward number range is seen to be below up to 1.5 standard deviations.

In our study, executive functions, namely, rule finding, category creation and category change, were evaluated using Wisconsin Card Sorting Test, and patients with AD had a significant difference compared to the normal group in these categories that were completed. Although $\mathrm{MCl}$ patients showed normal performance, a statistically significant difference was found when compared to the results of the normal group of our study. This was because the normal group had exceptionally high performances. There was no significant difference in the number of perseverative responses, percent of perseverative error, number of trials used to complete the first category, and percentage of conceptual level response between the $\mathrm{MCl}$ patients and the normal group in the detailed evaluation. However, patients with $\mathrm{MCl}$ were unsuccessful in maintaining the setup compared to the normal group. We think this finding can be explained by the argument that maintaining the setup is related to attention. In addition, in a study ${ }^{[16]}$ using factor analysis employing the Wisconsin Card Sorting Test, it was concluded that perseveration scores were the most important parameters and they were directly related to dorsolateral prefrontal cortex function. Therefore, perseveration scores are the number one parameter corresponding to executive functions. From this direction, 
Table 2. Result of Mann-Whitney $\mathrm{U}$ test for $\mathrm{AH}, \mathrm{MCl}$ and normal participants

\begin{tabular}{|c|c|c|c|c|c|c|}
\hline Variable & Group & $\mathbf{n}$ & Rank Mean & Rank Sum & U Test & $\mathbf{p}$ \\
\hline \multicolumn{7}{|l|}{ Wechsler Memory Scale } \\
\hline \multirow[t]{6}{*}{ Number Range } & $A D$ & 20 & 17.20 & 344.00 & 134.00 & 0.054 \\
\hline & $\mathrm{MCl}$ & 20 & 23.80 & 476.00 & & \\
\hline & $A D$ & 20 & 15.28 & 305.50 & 95.50 & 0.002 \\
\hline & Normal & 20 & 25.73 & 514.50 & & \\
\hline & $\mathrm{MCl}$ & 20 & 18.35 & 367.00 & 157.00 & 0.192 \\
\hline & Normal & 20 & 22.65 & 453.00 & & \\
\hline \multicolumn{7}{|l|}{ Reverse Number Range } \\
\hline & $A D$ & 20 & 13.60 & 272.00 & 62.00 & 0.000 \\
\hline & $\mathrm{MCl}$ & 20 & 27.40 & 548.00 & & \\
\hline & $A D$ & 20 & 12.78 & 255.50 & 45.50 & 0.000 \\
\hline & Normal & 20 & 28.23 & 564.50 & & \\
\hline & $\mathrm{MCl}$ & 20 & 18.73 & 374.50 & 164.50 & 0.292 \\
\hline & Normal & 20 & 22.28 & 445.50 & & \\
\hline \multicolumn{7}{|l|}{ Verbal Fluency Test } \\
\hline \multirow{6}{*}{ Animal Counting } & $A D$ & 20 & 15.30 & 306.00 & 96.00 & 0.005 \\
\hline & $\mathrm{MCl}$ & 20 & 25.70 & 514.00 & & \\
\hline & $A D$ & 20 & 10.85 & 217.00 & 7.00 & 0.000 \\
\hline & Normal & 20 & 30.15 & 603.00 & & \\
\hline & $\mathrm{MCl}$ & 20 & 16.25 & 325.00 & 115.00 & 0.021 \\
\hline & Normal & 20 & 24.75 & 495.00 & & \\
\hline \multirow[t]{6}{*}{ Animal Counting Perseveration } & $A D$ & 20 & 25.38 & 507.50 & 102.50 & 0.006 \\
\hline & $\mathrm{MCl}$ & 20 & 15.63 & 312.50 & & \\
\hline & $A D$ & 20 & 28.05 & 561.00 & 49.00 & 0.000 \\
\hline & Normal & 20 & 12.95 & 259.00 & & \\
\hline & $\mathrm{MCl}$ & 20 & 23.65 & 473.00 & 137.00 & 0.024 \\
\hline & Normal & 20 & 17.35 & 347.00 & & \\
\hline \multirow[t]{6}{*}{ K.A.S. Fluency } & AD & 20 & 15.03 & 300.50 & 90.50 & 0.003 \\
\hline & $\mathrm{MCl}$ & 20 & 25.98 & 519.50 & & \\
\hline & $A D$ & 20 & 13.45 & 269.00 & 59.00 & 0.000 \\
\hline & Normal & 20 & 27.55 & 551.00 & & \\
\hline & $\mathrm{MCl}$ & 20 & 18.60 & 372.00 & 162.00 & 0.304 \\
\hline & Normal & 20 & 22.40 & 448.00 & & \\
\hline \multicolumn{7}{|l|}{ K.A.S. Fluency } \\
\hline \multirow[t]{6}{*}{ Perseveration } & $A D$ & 20 & 22.83 & 456.50 & 153.50 & 0.177 \\
\hline & $\mathrm{MCl}$ & 20 & 18.18 & 363.50 & & \\
\hline & $A D$ & 20 & 25.60 & 512.00 & 98.00 & 0.002 \\
\hline & Normal & 20 & 15.40 & 308.00 & & \\
\hline & $\mathrm{MCl}$ & 20 & 22.90 & 458.00 & 152.00 & 0.107 \\
\hline & Normal & 20 & 18.10 & 362.00 & & \\
\hline \multicolumn{7}{|l|}{ WAIS-R } \\
\hline \multirow[t]{6}{*}{ Binary Similarities } & $A D$ & 20 & 10.58 & 211.50 & 1.50 & 0.000 \\
\hline & $\mathrm{MCl}$ & 20 & 30.43 & 608.50 & & \\
\hline & $A D$ & 20 & 10.58 & 211.50 & 1.50 & 0.000 \\
\hline & Normal & 20 & 30.43 & 608.50 & & \\
\hline & $\mathrm{MCl}$ & 20 & 19.45 & 389.00 & 179.00 & 0.494 \\
\hline & Normal & 20 & 21.55 & 431.00 & & \\
\hline \multirow[t]{6}{*}{ Proverbs } & AD & 20 & 20.13 & 402.50 & 192.50 & 0.789 \\
\hline & $\mathrm{MCl}$ & 20 & 20.88 & 417.50 & & \\
\hline & $A D$ & 20 & 20.25 & 405.00 & 195.00 & 0.858 \\
\hline & Normal & 20 & 20.75 & 415.00 & & \\
\hline & $\mathrm{MCl}$ & 20 & 20.63 & 412.50 & 197.50 & 0.928 \\
\hline & Normal & 20 & 20.38 & 407.50 & & \\
\hline
\end{tabular}


Table 2. CONT.

\begin{tabular}{|c|c|c|c|c|c|c|}
\hline Variable & Group & $\mathbf{n}$ & Rank Mean & Rank Sum & U Test & $\mathbf{p}$ \\
\hline \multicolumn{7}{|l|}{ Stroop Test } \\
\hline \multirow[t]{6}{*}{ Time Difference } & $A D$ & 20 & 25.88 & 517.50 & 92.50 & 0.004 \\
\hline & $\mathrm{MCl}$ & 20 & 15.13 & 302.50 & & \\
\hline & $A D$ & 20 & 27.98 & 559.50 & 50.50 & 0.000 \\
\hline & Normal & 20 & 13.03 & 260.50 & & \\
\hline & $\mathrm{MCl}$ & 20 & 24.55 & 491.00 & 119.00 & 0.028 \\
\hline & Normal & 20 & 16.45 & 329.00 & & \\
\hline \multirow[t]{6}{*}{ False } & $A D$ & 20 & 29.18 & 583.50 & 26.50 & 0.000 \\
\hline & $\mathrm{MCl}$ & 20 & 11.83 & 236.50 & & \\
\hline & $A D$ & 20 & 30.00 & 600.00 & 10.00 & 0.000 \\
\hline & Normal & 20 & 11.00 & 220.00 & & \\
\hline & $\mathrm{MCl}$ & 20 & 23.00 & 460.00 & 150.00 & 0.019 \\
\hline & Normal & 20 & 18.00 & 360.00 & & \\
\hline \multirow[t]{6}{*}{ Spontaneous Correction } & AD & 20 & 27.25 & 545.00 & 65.00 & 0.000 \\
\hline & $\mathrm{MCl}$ & 20 & 13.75 & 275.00 & & \\
\hline & $A D$ & 20 & 29.50 & 590.00 & 20.00 & 0.000 \\
\hline & Normal & 20 & 11.50 & 230.00 & & \\
\hline & $\mathrm{MCl}$ & 20 & 25.13 & 502.50 & 107.50 & 0.011 \\
\hline & Normal & 20 & 15.88 & 317.50 & & \\
\hline \multicolumn{7}{|l|}{ WCST } \\
\hline \multirow[t]{6}{*}{ Completed Category Number } & $A D$ & 20 & 12.68 & 253.50 & 43.50 & 0.000 \\
\hline & $\mathrm{MCl}$ & 20 & 28.33 & 566.50 & & \\
\hline & $A D$ & 20 & 10.50 & 210.00 & 0.00 & 0.000 \\
\hline & Normal & 20 & 30.50 & 610.00 & & \\
\hline & $\mathrm{MCl}$ & 20 & 16.88 & 337.50 & 127.50 & 0.007 \\
\hline & Normal & 20 & 24.13 & 482.50 & & \\
\hline \multicolumn{7}{|l|}{ Perseveration Reaction } \\
\hline \multirow[t]{6}{*}{ Number } & $A D$ & 20 & 26.80 & 536.00 & 74.00 & 0.001 \\
\hline & $\mathrm{MCl}$ & 20 & 14.20 & 284.00 & & \\
\hline & $A D$ & 20 & 29.83 & 596.50 & 13.50 & 0.000 \\
\hline & Normal & 20 & 11.18 & 223.50 & & \\
\hline & $\mathrm{MCl}$ & 20 & 23.70 & 474.00 & 136.00 & 0.083 \\
\hline & Normal & 20 & 17.30 & 346.00 & & \\
\hline \multicolumn{7}{|l|}{ Perseveration Fault } \\
\hline \multirow[t]{6}{*}{ Percentage } & $A D$ & 20 & 26.78 & 535.50 & 74.50 & 0.001 \\
\hline & $\mathrm{MCl}$ & 20 & 14.23 & 284.50 & & \\
\hline & $A D$ & 20 & 29.23 & 584.50 & 25.50 & 0.000 \\
\hline & Normal & 20 & 11.78 & 235.50 & & \\
\hline & $\mathrm{MCl}$ & 20 & 21.55 & 431.00 & 179.00 & 0.570 \\
\hline & Normal & 20 & 19.45 & 389.00 & & \\
\hline \multirow[t]{6}{*}{ First Category Completed Used Test Number } & r $A D$ & 20 & 25.78 & 515.50 & 94.50 & 0.004 \\
\hline & $\mathrm{MCl}$ & 20 & 15.23 & 304.50 & & \\
\hline & $A D$ & 20 & 26.03 & 520.50 & 89.50 & 0.002 \\
\hline & Normal & 20 & 14.98 & 299.50 & & \\
\hline & $\mathrm{MCl}$ & 20 & 19.75 & 395.00 & 185.00 & 0.669 \\
\hline & Normal & 20 & 21.25 & 425.00 & & \\
\hline \multirow[t]{6}{*}{ Conceptual Reaction Level Percentage } & $A D$ & 20 & 13.10 & 262.00 & 52.00 & 0.000 \\
\hline & $\mathrm{MCl}$ & 20 & 27.90 & 558.00 & & \\
\hline & $A D$ & 20 & 10.68 & 213.50 & 3.50 & 0.000 \\
\hline & Normal & 20 & 30.33 & 606.50 & & \\
\hline & $\mathrm{MCl}$ & 20 & 17.38 & 347.50 & 137.50 & 0.091 \\
\hline & Normal & 20 & 23.63 & 472.50 & & \\
\hline
\end{tabular}


Table 2. CONT.

\begin{tabular}{|c|c|c|c|c|c|c|}
\hline Variable & Group & $\mathbf{n}$ & Rank Mean & Rank Sum & U Test & $\mathbf{p}$ \\
\hline \multirow[t]{6}{*}{ Setup Prolongation Failure } & $A D$ & 20 & 24.85 & 497.00 & 113.00 & 0.012 \\
\hline & $\mathrm{MCl}$ & 20 & 16.15 & 323.00 & & \\
\hline & $A D$ & 20 & 27.68 & 553.50 & 56.50 & 0.000 \\
\hline & Normal & 20 & 13.33 & 266.50 & & \\
\hline & $\mathrm{MCl}$ & 20 & 24.05 & 481.00 & 129.00 & 0.008 \\
\hline & Normal & 20 & 16.95 & 339.00 & & \\
\hline \multicolumn{7}{|l|}{ Geriatric Depression Scale } \\
\hline \multirow[t]{6}{*}{ Geriatric Depression Scale } & $A D$ & 20 & 24.45 & 489.00 & 121.00 & 0.032 \\
\hline & $\mathrm{MCl}$ & 20 & 16.55 & 331.00 & & \\
\hline & $A D$ & 20 & 27.48 & 549.50 & 60.50 & 0.000 \\
\hline & Normal & 20 & 13.53 & 270.50 & & \\
\hline & $\mathrm{MCl}$ & 20 & 23.98 & 479.50 & 130.50 & 0.058 \\
\hline & Normal & 20 & 17.02 & 340.50 & & \\
\hline \multicolumn{7}{|l|}{ FBI } \\
\hline \multirow[t]{6}{*}{ FBI Negative } & $A D$ & 20 & 25.78 & 515.50 & 94.50 & 0.004 \\
\hline & $\mathrm{MCl}$ & 20 & 15.23 & 304.50 & & \\
\hline & $A D$ & 20 & 30.50 & 610.00 & 0.00 & 0.000 \\
\hline & Normal & 20 & 10.50 & 210.00 & & \\
\hline & $\mathrm{MCl}$ & 20 & 30.00 & 600.00 & 10.00 & 0.000 \\
\hline & Normal & 20 & 11.00 & 220.00 & & \\
\hline \multirow[t]{6}{*}{ FBI Disinhibition } & AD & 20 & 23.88 & 477.50 & 132.50 & 0.067 \\
\hline & $\mathrm{MCl}$ & 20 & 17.13 & 342.50 & & \\
\hline & $A D$ & 20 & 30.00 & 600.00 & 10.00 & 0.000 \\
\hline & Normal & 20 & 11.00 & 220.00 & & \\
\hline & $\mathrm{MCl}$ & 20 & 30.00 & 600.00 & 10.00 & 0.000 \\
\hline & Normal & 20 & 11.00 & 220.00 & & \\
\hline \multirow[t]{6}{*}{ FBI Total } & AD & 20 & 25.18 & 503.50 & 106.50 & 0.011 \\
\hline & $\mathrm{MCl}$ & 20 & 15.83 & 316.50 & & \\
\hline & $A D$ & 20 & 30.50 & 610.00 & 0.00 & 0.000 \\
\hline & Normal & 20 & 10.50 & 210.00 & & \\
\hline & $\mathrm{MCl}$ & 20 & 30.00 & 600.00 & 10.00 & 0.000 \\
\hline & Normal & 20 & 11.00 & 220.00 & & \\
\hline
\end{tabular}

our findings showed that AD patients differed significantly from both $\mathrm{MCl}$ patients and the normal group, and there was no difference between MCls and normal group. Compared to the scores reported in the BILNOT battery ${ }^{[17]}$, the scores of the patients with AD in our study were below the norms but not reaching 1.5 standard deviation below. A study ${ }^{[18]}$ compared plasma tau levels and cognitive functions in mild cognitive impairment and early Alzheimer's disease, the findings showed that plasma tau levels were higher both in $\mathrm{MCl}$ and early $\mathrm{AD}$ patients. As associated with the participants' WCST performance, plasma tau levels were positively significant and gray matter densities in hippocampus, amygdala and various regions were negatively significant in $\mathrm{MCl}$ and $\mathrm{AD}$ patients. Early $\mathrm{AD}$ patients had a lower performance than $\mathrm{MCl}$ patients, and $\mathrm{MCl}$ patients had a lower performance on WCST than healthy control. These results suggest that the prefrontal cortex functions, which can be argued as being protected in patients with early-stage $A D$ in the literature, is still partially preserved, but at this stage, it is thought to be starting to be affected.

The Stroop Test was used to evaluate the ability to inhibit inappropriate response. In this test, the findings showed that the normal group was more successful than the $\mathrm{MCl}$ patients and the $\mathrm{MCl}$ patients were more successful than the patients with AD. This difference was determined for all three sub-variables -namely, interference time, errors and spontaneous corrections-. Although the results of $\mathrm{MCl}$ and normal groups showed a statistically significant difference, they were quite close to each other. Another study ${ }^{[19]}$ examining the comparison of $\mathrm{AD}, \mathrm{MCl}$ and healthy aging using the Stroop task showed that even both $\mathrm{MCl}$ and $\mathrm{AD}$ patients had severe impairments in inhibition task; AD patients had lower performance. As seen in our study, literature findings ${ }^{[19,20]}$ also revealed that resistance to inter- 
ference is increasingly impaired in the later stages of the disease. When compared with the results of the study on normal subjects in Turkey ${ }^{[21]}$, it was seen that the duration of interference, the number of errors and the number of spontaneous corrections in $A D$ patients differ from the normative values up to 1.5 standard deviations. Moreover, patients with $\mathrm{MCl}$ showed a slightly lower performance than normative values. It can be said that the main neural infrastructure of the interference resistance test is the orbitofrontal cortex. When the progression of neurodegeneration in $A D$ is considered, it is expected that this paralimbic cortex will be privileged in the prefrontal cortex. Therefore, we believe that the poor performance in the Stroop test can be explained by this anatomical predisposition.

Verbal fluency was evaluated by Animal Counting and K.A.S. tests. In animal counting test, AD patients showed lower performance than $\mathrm{MCl}$ and normal groups. Phonemic fluency in the $\mathrm{MCl}$ group was not impaired based on the normal groups, whereas animal counting requiring the preservation of semantic information significantly affected. This situation suggests that semantic information is also affected by $\mathrm{MCl}$ cases, as defined in the literature ${ }^{[7]}$. For instance, Cooper et al. ${ }^{[22]}$ applied the semantic fluency test (animal counting) to $\mathrm{AD}$, amnestic $\mathrm{MCl}$ patients, and normal group two times with a one-week interval. It was observed that the normal group increased their performance in repeated tests; however, patients with $\mathrm{MCl}$ did not improve their performance, as well as the AD group. This situation is similar to our findings, which suggest that $\mathrm{MCl}$ patients are close to the AD group rather than the normal group in terms of semantic fluency. In another study ${ }^{[23]}$, researchers examined different verbal fluency tests (category and phonemic fluency) on AD patients and compared them with normal controls. In all verbal fluency tests, they found that category fluency was the most distinctive area with high precision. They explained that the fluency of the category has a more pronounced and earlier deterioration than other tests due to its semantic information structure. In the study of Moncsh ${ }^{[24]}$, they argued that the deterioration in category fluency showed the loss of semantic information in the early-stages of AD. When compared with the results of the study on normal subjects in Turkey ${ }^{[21]}$, it can be seen that according to the normative values in Turkey, categorical word fluency decreased in both $\mathrm{AD}$ and $\mathrm{MCl}$ patients, whereas phonemic fluency is below the norms only in $A D$ patients, but a 1.5 standard deviation difference did not exist.

There was no significant difference between the groups in the "Interpretation of Proverbs" evaluating thinking skills in abstract. When we examine the literature, since proverbs are well-learned conceptual expressions, they are not expected to be impaired in their interpretation in the early period of disorders ${ }^{[10]}$. In our study, this argument was supported, and Interpretation of Proverbs has been preserved in both $\mathrm{MCl}$ and $\mathrm{AD}$ patients. However, another study ${ }^{[25]}$ found that the impairment of proverb interpretation was less in $\mathrm{MCl}$ patients compared to early $\mathrm{AD}$ patients, but not significantly. In addition, Leyhe et al. ${ }^{[26]}$ examined amnestic $\mathrm{MCl}$ and early AD in proverb interpretation as a representative of executive functioning: amnestic $\mathrm{MCl}$ and early $A D$ patients had more impairment than healthy controls, also early $A D$ patients had given more meaningless answers.

Likewise, in the Binary Similarity Test which evaluates abstraction skills, results deteriorate from the early-stages of $A D$ as patients tend to find more concrete similarities instead of basic and abstract similarities. In accordance with this, in our study, it was observed that there was a significant deterioration in the $A D$ group when three groups compared with each other, but there was no difference between the $\mathrm{MCl}$ group and the normal group. Although $\mathrm{Bi}$ nary Similarity Test is accepted as a test which evaluates abstraction ability, to show better performance, it is needed to find out upper semantic category which two objects belong to in the same category. Innately, on one hand, it is abstraction while on the other hand language functions and semantic memory that should be optimum. It can be argued that AD group has impairments in both areas as binary similarity impairment is more related to a language function and semantic memory response than abstraction impairment. At least, we can state that it cannot be argued to be only abstraction impairment.

Patients with depression were excluded from our study for evaluating cognitive performance independently from other factors. In that purpose, although significant differences between groups were found between $A D, M C l$, and normal groups in their Geriatric Depression Scale scores, none of them were severe enough for a depression diagnosis. However, expectedly, scores were higher in AD patients that can be evaluated as having an insight about the disease that is not impaired yet at the early-stages of AD.

Frontal Behavior Inventory was applied to the patients' relatives to evaluate their behavioral problems. Some of the normal subjects' relatives could not be reached for the questionnaire; thus, this scale could not be completed for them. Therefore, only $\mathrm{AD}$ and $\mathrm{MCl}$ groups were compared concerning negativism, disinhibition and total behavior scores. The findings showed that while total behavioral 
scores had a statistically significant difference between $A D$ and $\mathrm{MCl}$ groups, behavioral disinhibition scores did not have statistically significant difference. AD group had severely significant behavioral change than the $\mathrm{MCl}$ group. This finding is thought to be due to our results' support for the statement that in the $\mathrm{MCl}$ group, only the limbic system structure is affected, but in the AD group, additionally, limbic system's prefrontal influence is starting. We argue that the reason beyond it was there is no found difference between disinhibition scores at the early-stage is the lack of behavioral problems in that stage.

As a result, in our study, MCl's general cognitive profile showed episodic and semantic memory impairment. Gomar ${ }^{[27]}$ compared working memory and executive functions in $\mathrm{MCl}, \mathrm{AD}$, and healthy controls. The findings showed that $A D$ patients have significantly more impairment than $\mathrm{MCl}$, while $\mathrm{MCl}$ patients were significantly worse than healthy controls. Attentional set-shifting, working memory and cognitive control were common deficits and impairments in some of these tests for $\mathrm{MCl}$ patients, which were explained as their possible episodic memory impairment. On the contrary, AD patients often had episodic and semantic memory impairments accompanying language, visuospatial scratch ability and some of executive functioning impairments. All groups comparisons show that all executive functions demonstrate the statistically significant differences with the $A D$ group being disadvantageous. However, when AD group's mean scores were evaluated with the normative scores in the literature concerning executive function scores -except Binary Similarity and Stroop Test interference time, false, and spontaneous correction-, it was observed that the criteria of individual evaluation of impairment's at least one standard deviation below the normative value did not meet. Those results are congruent with the hypothesis mentioned before stating prefrontal heteromodal, which is the neural substructure of executive functioning, is not impaired by the loadings of the posterior heteromodal cortex at the early-stages of AD yet.

In our study, we observed that $\mathrm{MCl}$ patients showed different performances for semantic fluency, which made us argue that patients with $\mathrm{MCl}$ whose semantic network was not degenerated yet like the others in the same spectrum can be argued to be close to normal, while other patients with $\mathrm{MCl}$ with apparent impairment are closer to the $A D$ group of whom prefrontal limbic degeneration starts very early. For future studies, using larger groups of patients with $\mathrm{MCl}$ diagnosis may enable researchers to examine semantic fluency performance preceding the inclusion of the patients with impaired semantic fluency performance to the group of AD diagnosis, while others included to the normal group. We believe that this information can be a promising factor in distinguishing the fine boundary between $\mathrm{MCl}$ and early-stage AD with an opportunity for early diagnosis and treatment of AD. Lastly, the impairment in sleep may be a risk factor for developing $A D$, and sleep problems may lead to attention deficits. In this context, it can be helpful to examine sleep problems of $\mathrm{MCl}$ and $\mathrm{AD}$ patients to explain the dynamics behind their attention deficits rather than evaluating it as related to depression only ${ }^{[11]}$.

Peer-review: Externally peer-reviewed.

Authorship Contributions: Concept: H.G., A.F.; Design: E.N.T., A.F.; Data Collection or Processing: A.F.; Analysis or Interpretation: A.F.; Literature Search: A.F.; Writing: E.E.

Conflict of Interest: None declared.

Financial Disclosure: The authors declared that this study received no financial support.

\section{References}

1. Petersen RC, Smith GE, Waring SC, Ivnik RJ, Tangalos EG, Kokmen E. Mild cognitive impair-ment: clinical characterization and outcome. Arch Neurol 1999;56:303-8. [CrossRef]

2. Knopman DS, Boeve BF, Petersen RC. Essentials of the proper diagnoses of mild cognitive im-pairment, dementia, and major subtypes of dementia. Mayo Clin Proc 2003;78:1290-308.

3. Celsis P. Age-related cognitive decline, mild cognitive impairment or preclinical Alzheimer's disease? Ann Med 2000;32:614. [CrossRef]

4. Morris JC. The Clinical Dementia Rating (CDR): current version and scoring rules. Neurology 1993;43:2412-4. [CrossRef]

5. Rubin EH, Morris JC, Grant EA, Vendegna T. Very mild senile dementia of the Alzheimer type. I. Clinical assessment. Arch Neurol 1989;46:379-82. [CrossRef]

6. Morris JC. Alzheimer Hastalığının Klinik Sunum ve Seyri. In: Gürvit IH (Translation Editor). Alz-heimer Hastalığı. İstanbul: Yelkovan Yayıncılık, 2001.

7. Salmon DP, Bondi MW. Alzheimer Hastalığının Nöropsikolojisi. In: Gürvit ï (Translation Edi-tor). Alzheimer Hastalığı. İstanbul: Yelkovan Yayıncılık, 2001.

8. Bäckman L, Andersson JL, Nyberg L, Winblad B, Nordberg A, Almkvist O. Brain regions associat-ed with episodic retrieval in normal aging and Alzheimer's disease. Neurology 1999;52:1861-70. [CrossRef]

9. Bondi MW, Serody AB, Chan AS, Eberson-Shumate SC, Delis DC, Hansen LA, et al. Cognitive and neuropathologic correlates of Stroop Color-Word Test performance in Alzheimer's disease. Neu-ropsychology 2002;16:335-43. [CrossRef]

10. Öktem Ö. Alzheimer Hastalığının Erken, Orta ve İleri Dönemlerinde Genel Kognitif Profil. In: Karakaş S, İrkeç C, Yüksel N (editors). Beyin ve Nöropsikoloji. Ankara: Çizgi Tıp Yayınevi, 2003. 
11. Hennawy M, Sabovich S, Liu CS, Herrmann N, Lanctôt KL. Sleep and Attention in Alzheimer's Disease. Yale J Biol Med 2019;92:53-61.

12. Berardi AM, Parasuraman R, Haxby JV. Sustained attention in mild Alzheimer's disease. Dev Neuropsychol 2005;28:507-37.

13. Weintraub S. Mental Durumun Nöropsikolojik Değerlendirilmesi, Davranışsal ve Kognitif Nörolojinin İlkeleri. 2nd ed. İstanbul: Yelkovan Yayıncılık, 2001.

14. Lezak MD. Neuropsychological Assessment. 3rd ed. New York: Oxford University Press, 1995.

15. Özdeniz E. Bir Grup Sağ Hemisfer ve Dikkat Testleri Performansına Yaş ve Eğitim Değişken-lerinin Etkisi. İstanbul: İstanbul Univ; 2001.

16. Greve KW, Stickle TR, Love JM, Bianchini KJ, Stanford MS. Latent structure of the Wisconsin Card Sorting Test: a confirmatory factor analytic study. Arch Clin Neuropsychol 2005;20:355-64.

17. Karakaş S. Bilnot Bataryası El Kitabı: Nöropsikolojik Testler İçin Araştırma ve Geliştirme Çalışmaları. Ankara: Dizayn Ofset; 2004.

18. Chiu MJ, Chen YF, Chen TF, Yang SY, Yang FP, Tseng TW, et al. Plasma tau as a window to the brain-negative associations with brain volume and memory function in mild cognitive impair-ment and early Alzheimer's disease. Hum Brain Mapp 2014;35:3132-42. [CrossRef]

19. Bélanger S, Belleville $S$, Gauthier S. Inhibition impairments in Alzheimer's disease, mild cog-nitive impairment and healthy aging: effect of congruency proportion in a Stroop task. Neuro-psychologia 2010;48:581-90. [CrossRef]

20. Lee DY, Seo EH, Yun JY, Choo IH, Park SY, Kim SG, et al. Neu- ral Correlates of the Stroop Test Performance in Patients with Alzheimer's Disease: An FDG-PET Study. Alzheimer's \& Dementia J Alzheimer Assoc 2011;7:75. [CrossRef]

21. Tumaç A. Normal Deneklerde, Frontal Hasarlara Duyarlı Bazı Testlerde Performansa Yaş ve Eğitimin Etkisi. İstanbul: İstanbul Univ; 1997.

22. Cooper DB, Lacritz LH, Weiner MF, Rosenberg RN, Cullum CM. Category fluency in mild cog-nitive impairment: reduced effect of practice in test-retest conditions. Alzheimer Dis Assoc Dis-ord 2004;18:120-2. [CrossRef]

23. Monsch AU, Bondi MW, Butters N, Salmon DP, Katzman R, Thal LJ. Comparisons of verbal flu-ency tasks in the detection of dementia of the Alzheimer type. Arch Neurol 1992;49:1253-8.

24. Monsch AU, Seifritz E, Taylor KI, Ermini-Fünfschilling D, Stähelin HB, Spiegel R. Category flu-ency is also predominantly affected in Swiss Alzheimer's disease patients. Acta Neurol Scand 1997;95:81-4. [CrossRef]

25. Batum K, Çinar N, Sahin S, Çakmak MA, Karşidağ S. The connection between $\mathrm{MCl}$ and $\mathrm{Alz}$-heimer disease: neurocognitive clues. Turk J Med Sci 2015;45:1137-40. [CrossRef]

26. Leyhe T, Saur R, Eschweiler GW, Milian M. Impairment in proverb interpretation as an exec-utive function deficit in patients with amnestic mild cognitive impairment and early Alzheimer's disease. Dement Geriatr Cogn Dis Extra 2011;1:51-61. [CrossRef]

27. Gomar JJ. Breadth and Depth of Working Memory and Executive Function Compromises in Mild Cognitive Impairment $(\mathrm{MCl})$ and Alzheimer's Disease (AD). Alzheimer's \& Demen-tia: J Alzheimer Assoc 2017;13:1398-99. [CrossRef] 